\title{
ECONOMIES OF PRIVATE SECTOR PARTICIPATION IN SOLID WASTE MANAGEMENT IN TAKORADI - A GHANAIAN CITY
}

\author{
R. D. Dinye \\ Centre for Settlements Studies \\ Institute of Human Settlements Research (IHSR) \\ Kwame Nkrumah University of Science and Technology Kumasi, Ghana.
}

\begin{abstract}
Without going into the complex intricacies of the controversial privatisation debate that have since the 1980s ensued, this paper evaluates the economic feasibility of private sector participation in solid waste management in a Ghanaian city context. The criteria for identifying viable economic opportunities for investment are contingent to the prevailing market conditions. The primary consideration, inevitably, is the potential profit that can be derived. On the supply side, the weight of the premium placed on borrowed capital is a fundamental determining factor. On the demand side, the business prospects of private sector participation in solid waste management depends on the nature and the scale of cost recovery consequent upon the payment regime negotiated and accepted by the residents. It has been established through a case study of Takoradi that private sector participation in solid waste management in the city is a viable business venture within certain contextual conditions. An important consideration is the ability and willingness to pay by the residents. The designated payment regime is such that the returns are adequate to finance the service provision and leave a modest outlay to the investor as profit. On the part of the investor, the ease of access to investment capital and a congenial macro-economic environment are important determinants of successful business.
\end{abstract}

Keywords: Solid Waste Management, Private Sector, Participation.

\section{INTRODUCTION}

Cities are an inevitable consequence of human life. They, therefore, encompass the totality of the civilisation of mankind. Both the development and regression of humanity are indeed a tale of cities built and lived in. The United Nations defines a city as a settlement with 100,000 or more inhabitants. Ghana adopts that definition in the conduct of its censuses and by that, recorded eight cities in its most recent population headcount in the year 2000. These Ghanaian cities are Accra $(1,658,937)$, Kumasi $(1,170,270)$, Tamale $(202,317)$, Takoradi $(175,436)$, Ashiaman $(150,312)$, Tema $(141,479)$, Obuasi $(115,564)$ and Sekondi $(114,157)$ - (Ghana Statistical Service, 2002).

The origin, growth and development of the cities are the result of rapid population growth and an attendant urbanisation. In Ghana, the trend of urbanisation has been on ascendancy since its independence in 1957. Sustained population growth over the past five decades sparked off an increase in the numbers and sizes of towns and cities in the country (Kasanga and Avis, 1988). Ghanaian cities, like those in other developing countries are, therefore, confronted with a myriad of problems which include disintegrating infrastructure, inefficient services, eroding revenue basis and weak administrative systems. Basically, they experience two interrelated structural problems. One of them is their incapacity to employ and accommodate their rapidly increasing populations and prevent environmental degradation. The other problem is the lack of infrastructural base and managerial framework to effectively occasion the implementation of their transformation processes. Cities are at a great risk from hazards and from their own vulnerabilities. A blow to any of them will ripple through the entire socio-economic and political fabric of its network (Tibaijuka, 2001). A strategic urban management system is, therefore, imperative to prevent the advent of city decay and to enhance their economic competitiveness.

On grounds that they are strategically managed, urbanisation and city growth are catalysts to the processes of national socio-economic transformation, growth and development. At the instance of Ghana, however, there is hardly any evidence of good urban management practice for even smaller towns, let alone for the cities. The rapid growth of cities is a big challenge to development for it adversely puts an unprecedented pressure on their functions, which include waste management. Against the background of the ensuing problems occasioned by the growth of the cities, this paper seeks to draw the attention of metropolitan authorities to the economies of private sector participation in the management of the cities. With special 
reference to solid waste management, the paper describes a case study evaluation of the feasibility of private sector participation in Takoradi, Ghana's third largest city.

Solid-waste management in cities is of crucial importance, because of its impact on both health and other infrastructure. The huge volumes of the urban waste generated can adversely affect their water, sanitation and drainage systems. This results in poor water quality, stagnant water and floods, which pose risks to human lives. Through these mechanisms diseases are spread by vectors and contamination by direct contact. Poor solid waste management also directly affects waste workers and waste-pickers. Inadequate waste management can also lead to physical hazards such as floods and fire outbreaks.

Private sector involvement in the solid waste management in Ghanaian cities demands the understanding of a number of issues which constitute the hallmark of this paper. These include: i) the nature of the existing solid waste management system; ii) the ability and willingness of the inhabitants to pay; and iii) the economies of the private sector investment in the solid waste management as a venture. The objective is to contribute to the debate on public versus private provision of utility services. The paper does so by assessing the economic feasibility of private sector investment in solid waste management. The reader is called to mind and appreciate that there are other equally important factors including political and social considerations that affect investment decisions. For analytical convenience, the focus in this scope is on the economies, more particularly the financial feasibility of the private sector participation in waste management as a business activity.

Much understanding of the underlying causes of the public sector's inadequate performance is necessary for judgement of the economic, social and technical viability of new or alternative approaches to solid waste management in Ghanaian cities. The reasons generally given for the poor performance are, for example, lack of resources, institutional weakness, and lack of political will or an uneducated population. These need to be much more closely defined and analysed. For innovative approaches to policy and practice to have any chance of success, it is important to understand why and when the need for solid waste management services is so serious, there appears to be a lack of the attendant sensitivity and drive to match it (Chaplin, 1999; Burra et al, 2003).

\section{THE CHALLENGE}

Solid waste management is one of the key factors that contributes to the overall health and economic development of cities. In most parts of the world, the responsibility of solid waste management is placed in the hands of local government, be it metropolitan, municipal or otherwise through various legislative instruments and Acts. In Ghana, the Local Government Law (1988) PNDC Law 207 and the Local Government Act 262 (1993) empower the Metropolitan, Municipal and District Assemblies to undertake waste management and enact bye-laws to regulate the effective management of waste in their respective jurisdictions. The huge heaps of garbage and refuse, as well as the unsanitary conditions in Ghanaian cities are an indication that the responsible public sector bodies have not lived up to the task.

Since the 1990s, private sector participation in public utilities and service delivery has vigorously been advocated as a means of attaining greater efficiency in their production and distribution in developing nations (Gutierrez, 2001). There is a general notion that public utilities have been slow in extending access to services and that they can be inefficient and even corrupt (Budds and McGranahan, 2003). Hitherto, private sector participation remains controversial. The debate is ostensibly about public interest, but what makes the conflict of private involvement contentious, is the vested interests of the primary actors within the utility service provision sector. Whilst actors in the private sector are keen in pursuing profits, public sector employees are zealous in the protection of their jobs. The private versus the public sectors' debate is an unhealthy one, in that it obscures the variety of roles both sectors can play in city management and therefore makes it easy for the unfolding process of private involvement to be relegated. Under the right environmental context, it is quite possible for private sector participation, not only to improve efficiency, but to increase the financial resources available for better city management.

\section{RESEARCH METHODOLOGY}

The study, which provided the basis for this paper, covered seven publicly planned and developed residential neighbourhoods in Takoradi with a total population of 92,060 and a housing stock of 1,870 houses (Land valuation Board, 2004). The selected neighbourhoods are Chapel Hill, Beach Road, Airport Ridge, Windy Ridge, Tadisco Down, Esikafo Ambantem and Takoradi Central. A sample of 187 houses, 
representing about $10 \%$ of the total number of housing units $(1,870)$ in the planned residential areas, were randomly selected for the household survey. Cluster sampling method was used amounting to the distribution of the sample size among the various residential areas based on the total number of housing units in each of them. The distribution is presented in Table 1. In each of the selected houses, one household head was interviewed through the use of a questionnaire. The output was valuable in assessing the willingness and ability of residents to pay for solid waste management services by the private sector. For the feasibility analysis and synthesis, data drawn from the empirical household survey were complemented with information derived from secondary sources through desk research.

\section{Solid waste management and private participation}

Solid waste is defined as useless, unwanted or discarded material that arises from man's activities and is not free flowing. It may be classified into garbage (decomposable waste from food); rubbish (nondecomposable waste); and ash (residue from combustion of solid fuels). On a much broader perspective, it can be classified as household waste, commercial waste, industrial waste, mining waste, ashes, agricultural waste and waste from demolition (Skitts, 1979). Solid waste management refers to the collection, storage, transportation treatment and disposal of solid materials resulting from human and animal activities

Table 1: Sample of houses selected from residential areas in Takoradi

\begin{tabular}{lccc}
\hline \multicolumn{1}{c}{ Residential Area } & No. of Houses* & $\begin{array}{c}\text { As \% of Total No. } \\
\text { of Houses }\end{array}$ & Sample Size (10\%) \\
\hline Chapel Hill & 242 & 12.9 & 24 \\
Beach Raod & 192 & 10.3 & 19 \\
Airport Ridge & 243 & 13.0 & 24 \\
Windy Ridge & 130 & 7.0 & 14 \\
Tadisco Down & 262 & 14.0 & 26 \\
Esikafo Ambantem & 241 & 12.8 & 24 \\
Takoradi Central & 560 & 30.0 & 56 \\
\multicolumn{1}{c}{ Total } & $\mathbf{1 8 7 0}$ & $\mathbf{1 0 0}$ & $\mathbf{1 8 7}$ \\
\hline
\end{tabular}

*Source: Ghana Land Valuation Board, Takoradi Office, 2004

For the purpose of this paper, "private sector participation" refers to processes that increase the involvement of formal private enterprises in sanitary service provision and management but does not necessarily amount to the transfer of assets to the private operator. Hartman (1995) noted that the provision of solid waste management via the private sector promotes high efficiency, equity and accountability to users and financiers. Idelovitsch and Ringskog (1995) indicate that the efficiency gains result in cost savings that can generate investment funds through easy access to private capital.

The situation is not such that there is no known means of dealing with the solid waste problems in Third World cities and therefore in Ghana. Available literature indicate that more effective environmental and specifically sanitation policies can emanate from the stand point of questions addressing issues of governance, political will, poor management, available resources, inter-agency rivalry, poor data collection and lack of information, equity and popular attitudes (Fransen,1999).

Private Sector participation in utility service provision and management is rooted in the broad conception of privatization which is an embodiment of the neo-liberal orthodoxy. The neo-liberal ideology holds that social as well as economic functions should be undertaken by businesses under a free market mechanism. Within that context, the state through the political process is to play a facilitating and regulatory role without direct engagement (Gutierrez, 2001). According to Fransen (1999), the main driver for a successful private sector involvement in solid waste management is competition, accountability and transparency between customers and service providers. It is critical to note that the private sector per se necessarily does not create efficiency but the competition it brings about. Throughout history, competition has driven economic progress through better service generation. 
A successful private sector involvement in solid waste management, according to Fransen (1999), should satisfy the following strategic conditions: common interest, common plan development, spreading profits and losses and legal framing. The real interests of the potential partners must be verified, for frustrations tend to arise if commitment is not apparent. Stakeholder consultation and participation in decision-making at all stages of the planning process cannot be compromised. This is to avoid waste in capital investment in the event that the plan has to be fundamentally changed or discarded altogether. Conflicts and differences may arise and all efforts must be made to minimise the chances of the occurrence. Prior to the formulation of an agreement, an initial phase of acquaintance, study, definition of preconditions, covenant or letter of intent have to be arranged. Where the private partner is to heavily invest, extra legal sureties should be formulated to guarantee security.

Cointreau (1994) identified contracting, concession, franchaise and open competition as the most common types of private sector participation in solid waste management. According to Donohue (1989), the service involves low economies of scale, technological simplicity and moderate investment. It is generally observed that private firms engaged in contracting services are mostly small and medium sized firms (Bartone, 1991). Stotman (2000) outlined more options which are distinguishable by the degree of involvement of the private sector, the risks for both the private and the public sectors, the duration of contracts and the contractual relationship with the customer. The typical forms of private sector involvement in sanitary utility service delivery, with numerous variations, depending on the legal and regulatory frameworks, the nature of the company and the type of contract are briefly described as summarized in Table 2.

Service contract: these are usually short-term agreements whereby a private contractor takes responsibility for a specific task, such as house-to-house refuse collection for a fixed or per unit fee.

Management contracts: the government transfers certain operation and maintenance responsibilities to a private company but retains responsibility for investment and expansion. Payment is either fixed or performance related.

Table 2: Allocation of Key Responsibilities for Private Options

\begin{tabular}{|c|c|c|c|c|c|c|}
\hline Responsibility & $\begin{array}{l}\text { Service } \\
\text { contract }\end{array}$ & $\begin{array}{l}\text { Management } \\
\text { contract }\end{array}$ & Lease/affermage & Concession & BOT-type & Divestiture \\
\hline Asset ownership & Public & Public & Public & Public & $\begin{array}{l}\text { Private/ } \\
\text { public }\end{array}$ & Private \\
\hline $\begin{array}{l}\text { Capital } \\
\text { investment }\end{array}$ & Public & Public & Public & Private & Private & Private \\
\hline Commercial/risk & Public & Public & Shared & Private & Private & Private \\
\hline $\begin{array}{l}\text { Operations/ } \\
\text { Maintenance }\end{array}$ & $\begin{array}{l}\text { private/ } \\
\text { public }\end{array}$ & Private & Private & Private & Private & Private \\
\hline Contract duration & $1-2$ years & $3-5$ years & $8-15$ years & 25-30 years & $\begin{array}{l}20-30 \\
\text { years }\end{array}$ & indefinite \\
\hline
\end{tabular}

Source: Curled from Jessica Budds and Gordon McGranahan (2003)

Lease and affermage contracts: these are similar to management contracts, but the private operator takes responsibility for all operation and maintenance functions, including billing and revenue collection. In both cases, the operator collects the tariff revenue but, under an affermage, the contractor is paid an agreed-upon fee for each unit of service produced and distributed. Under a lease, the operator pays a lease fee to the public sector and retains the remainder.

Concession contracts: the private contractor manages the entire utility and is required to invest in the maintenance and expansion of the system at its own commercial risk. Concessions have longer terms to allow for the operator to recoup the investment. At the end of the contract, the assets are either transferred back to the state or a further concession is granted. The role of the government is predominantly regulatory.

BOT (Build-Own-Transfer) type contracts: Under these arrangements, the private contractor is responsible for the procurement, construction and management of the infrastructure from scratch with the government purchasing the supply. The assets either remain indefinitely with the private company or are transferred back to the state at the end of the contract. 
Divestiture: This refers to a situation where the government transfers the business, including the infrastructure, to the private company on a permanent basis through the sale of some or all of the shares in the company.

In addition to the above schemes, other options of private sector participation include joint ventures and cooperatives. A joint venture is an arrangement whereby a private company forms a company with the public sector. The private investor normally takes a contract for the utility management.

\section{Existing situational analysis of the SEAM (Takoradi) area}

Rapid population growth and urbanisation as being experienced in Takoradi and the other cities of Ghana create untold solid waste management and environmental problems. City authorities can hardly find the antidote due to the limited and even dwindling human, equipment and financial resources that are available to them.

The government of Ghana through the Urban Environmental and Sanitation Programme (UESP IV) seeks to privatize house to house solid waste collection in the five major cities (Accra, Kumasi, SekondiTakoradi, Tema and Tamale) in the country. As a result, private sector participation in solid waste management started in Ghana 1992 and has since been in operation in Accra, Tema, and Kumasi. It is, however, an evolving process and has not yet been fully explored.

The private sector participation that the Government of Ghana seeks to promote is by way of granting concessions. In concession contracts, the private contractor is to manage the entire house to house solid waste collection in a specified area. The contractor is required to invest in the maintenance and expansion of operational mechanism at its own commercial risk. Concessions have longer terms to allow the operator to recoup the investment. At the end of the contract, the assets are either transferred back to the state or a further concession is granted. The role of the government is predominantly regulatory.

Takoradi has been selected for this study because it is the next city in which the project is to be implemented. The introduction of the privatization scheme into Takoradi thus needs an ex-ante assessment of the project viability in its case specific context. The results of this study are intended to be a forerunner contributory complement to the feasibility work to be conducted in lieu of the house to house solid waste collection project in Takoradi.

Hard statistical information on solid waste generation in the various residential areas was not readily available. The total volume of waste generated in Takoradi in a week in 2005 was estimated to be about 47.70 tons considering the existing population and the solid waste generation rate of $0.5 \mathrm{~kg}$ per capita daily (Okai, 2003 Unpublished). In Takoradi, the solid waste management system has virtually broken down with many areas of the city receiving no services. The Shama Ahanta East Metropolitan Assembly (SAEMA), lacks the pertinent resources to effectively manage the large volumes of solid waste generated within its jurisdiction although that is its statutory responsibility. The metropolitan assembly or otherwise the public sector is constrained by an amalgam of problems. To secure improvements in the solid waste management system in terms of efficiency, quality service and coverage, the participation of the private sector is a considered option.

According to the Waste Management Department, some of the key problems, which hamper the effective delivery of waste management services by SAEMA include the following:

Inadequate funding provided by the central government;

Inadequate equipment holding resulting in limited coverage of service delivery;

Inadequate bye-laws and lack of enforcement of the existing ones;

Inadequate revenue mobilization to finance solid waste management service cost;

Solid waste collection and disposal services have been provided for free over the years causing unwarranted strain on the city's limited financial resources;

Bad attitudes of residents such as indiscriminate disposal of household waste and public littering due to ineffective environmental health education and service promotion strategy;

Poor infrastructural conditions particularly road network and waste collection points mostly in new settlements, which impact negatively on service delivery;

Inappropriate design of communal containers. The high reach of containers results in waste being thrown on the ground particularly by children; and 
No definite designated permanent landfill sites as of now.

These and other reasons are generally given, for example lack of resources, institutional weakness, lack of political will or an uneducated population, need to be much more closely defined and analysed.

\section{Solid Waste Disposal}

The refuse disposal sites in the residential areas are inadequate. The residents, as a result, resort to unacceptable refuse disposal alternatives. Unorganised refuse dumps have been created by the residents on vacant or undeveloped plots. Rake and burn technologies are normally practised at these refuse dumps sites. Since this method is not effectively carried out on regular basis, the result has been the breeding of rodents and other agents of health hazard generation. The proportion of the inhabitants with access to public refuse dumps amounted to 27.2 percent. The other solid waste disposal methods practised by the people in Takoradi comprise burial (4.7 percent), burning (10.7 percent) and indiscriminate dumping (48.2 percent) on unauthorised sites. The refuse at official designated sites is not cleared on time until it assumes a state that warrants public out cry.

The households mostly use refuse containers such as plastic buckets (57 percent), metal buckets (23 percent) and polythene bags ( 20 percent) to store refuse in their homes before finally disposing it off. The disposal of the refuse is done daily normally early in the morning. It is done mostly by children between the ages of 8-15 years. Most of them dump the refuse into drains and nearby bushes since the few refuse dump sites are $0.5 \mathrm{~km}$ distance away from many houses.

\section{Willingness to Pay for Services by Residents}

The residents in all the residential areas saw the lack of refuse collection services in their neighbourhood as a serious threat to a clean environment and public health, and are therefore willing to contribute towards the provision of an efficient and effective service by a private firm. The average monthly household income was $\phi 530,962$. The various amounts residents were willing to pay ranged from $\phi 25,000$ (63 percent) through $\notin 30,000$ (27 percent) to $\Varangle 35,000$ (10 percent). Whilst the lowest $(\varnothing 25,000)$ suggested payment regime fell short of the prevailing rates in Kumasi, Accra and Tema in Ghana, the latter two were more or less in tune.

Most of the respondents unwilling to pay beyond $ф 25,000$ were the residents of Takoradi Central neighbourhood where the household income of each the respondents captured in the study fell below the overall average household income of $\phi 530,962$. Arguments advanced by those in the lower income brackets for their unwillingness to pay for services by a private contractor included the following:

It is the responsibility of the S.A.E.M.A. to provide that service free of charge, whether improved or not;

The fees to be paid would be high and we cannot afford it;

The private contractor would also not be efficient as time goes on; and

The S.A.E.M.A. should recruit more sanitary workers if its staff strength is inadequate.

\section{Analytical framework of private sector participation \\ Assumptions}

In analysing the economic feasibility of private sector participation, the following assumptions have been made:

The real impact of such a project would be realized over a ten year period due to the level of capital outlay required;

The analysis is based on the projection of the 2005 prices using an inflationary rate of 16.5 percent per annum;

Time for normal round trip including collection, discharging at a disposal site and return is 3.5 hours;

Working hours per day are eight hours at six working days per week;

Average distance per round trip is 15 kilometres;

Average fuel consumption per 100 kilometres is 15 litres;

The cost of lubricants is about 85 percent of fuel cost taking into consideration the almost 50 percent petroleum products price increase;

The replacement rate of the capital equipment will be after seven years at a scrap value of 40 percent of 
initial cost;

The frequency of refuse collection will be twice a week;

The level of participation will be 100 percent by the resident population;

Exchange rate of a US dollar to the cedi is $\phi 9,200$;

Bye-laws on sanitation would be strictly enforced, compelling all residents and households to participate fully in the scheme; and

Any future changes in user fees will be taken care of by the discount rate-the benefit/revenue is held constant.

\section{EMPIRICAL RESULTS}

The privatised house to house collection would be effective if the capacity of the refuse of the contractor is optimally utilized. As a result collection should be such that all refuse generated are cleared by the contractor with a certain minimum capacity. Considering the volume of refuse generated per annum within the pilot areas, the minimum capacity of refuse collection vehicle should be two (2) compactor (18 cubic metres) refuse trucks. To operate this capacity the contractor will require a five man staff made up of an accounts clerk, a foreman, a revenue collector(s), 2 drivers and 4 labourers. The choice of this technology is based on the Accra and Kumasi experience where a similar pilot projects were implemented, following which a decision of full privatization was reached.

The total capital cost is $\phi 1,171,076,420$ comprising an owing cost of $\phi 800$ million capital and the running cost of $\phi 371,076,420$ million per annum. The two refuse compactor trucks are expected to depreciate at a cost value of $\phi 3,809,533.81$ per month to eventually leave a residual scrapped capital value of $\$ 320,000,000$ at the end of seven years. The estimated running costs are shown in the Table 3 .

Table 3: Estimated operational cost of proposed solid waste project in Takoradi

\begin{tabular}{lcrr}
\hline \multicolumn{1}{c}{ Running Cost } & Duration & Cost/Month & \multicolumn{1}{c}{ Cost/Year } \\
1. Spare Parts/ Maintenance & 12 Months & $10,000,000$ & $120,000,000$ \\
2. Fuel & 12 Months & $3,000,000$ & $36,000,000$ \\
3. Lubricants & 12 Months & $3,250,000$ & $39,000,000$ \\
4. Admin. Overheads and Salaries & 12 Months & $14,673,035$ & $176,076,420$ \\
Total & $\mathbf{1 2}$ Months & $\mathbf{3 0 , 9 2 3 , 0 3 5}$ & $\mathbf{3 7 1 , 0 7 6 , 4 2 0}$ \\
\hline
\end{tabular}

Estimated Benefits from Willingness to Pay

The revenue or the attendant anticipated concomitant benefits that can accrue are from the different payment regime and the scrapped value of the capital investment viz. the two refuse collection trucks. This discounted value of the refuse collection trucks is $\$ 320,000,000$ in the seventh year of their lifecycle. The estimated benefits that will accrue are of course different under the different payment regimes. The $\phi 25,000$ monthly payment regime will generate an annual value of $\phi 561,000,000$ whilst the $\phi 30,000$ regime will result in $\phi 673,200,000$. The third monthly payment scenario $(\phi 35,000)$ will generate an annual revenue of $\notin 785,400,000$.

\section{Feasibility Analytical Methods}

Cost-Benefit Analysis (CBA): The CBA is a broad term covering analysis which compares the cost and benefits of a particular project.

Discount Rate: This is the rate at which a project's annual cost and benefits are discounted to produce the project Net Present Value. It measures the fall in value of net benefit over time. The process of discounting applies a weight to the measures in different years to convert them to a common base. The base year which is the year in which the investment is made, is denoted year ' 0 ' of the project. The weight applied in different years is known as the discount factor and it depends upon the chosen discount rate derived from the dynamics of the econqmic environment, such as inflation.

Mathematic ally, $\mathbf{d f}=\frac{}{(1+\mathrm{r})^{t}}$

df $=$ the discount factor 
$\mathrm{r} \quad=\quad$ the discount rate

$\mathrm{t}=$ the number of years after 0

The anticipated Takoradi solid waste management project's costs and benefits were discounted to get their net present values using computer Microsoft word excel programme which generated the results once the necessary elemental factor value inputs were made. The outputs obtained are as presented in table $4 \mathrm{a}, 4 \mathrm{~b}$, $5 \mathrm{a}, 5 \mathrm{~b}, 6 \mathrm{a}$ and $6 \mathrm{~b}$.

Benefit-Cost Ratio (BCR): The BCR is one of the decision criteria used to decide whether a project proposal is acceptable or not. For a project to be acceptable, the discounted value of its benefits should exceed the discounted value of the costs

$$
\mathrm{BCR}=\frac{\sum_{\mathrm{t}}(\mathrm{B}(\mathrm{t}))}{\frac{\sum_{\mathrm{i}+\mathrm{r})^{t}}(\mathrm{C}(\mathrm{t}))}{(i+r)^{t}}}
$$

For example the $\notin 25,000$ monthly payment rate per house,

the Discounted Benefits is $\notin 270,5179,070$; and the Discounted Cost is $\notin 2,756,971,629$

Therefore the benefit Cost Ratio

$=\varnothing 2,705,179,070 / \not 2,756,971,629$

$$
=0.98: 1
$$

Where $\mathrm{r}=$ the discount rate, $\mathrm{t}=$ the number of years from the base year, $\mathrm{B}(\mathrm{t})=$ total benefits in year $\mathrm{t}, \mathrm{C}(\mathrm{t})=$ total costs in year $\mathrm{t}$

Once the costs and benefits were discounted the benefit cost ratio for the various monthly payment regimes could be calculated using the following formula:

Benefit Cost Ratio $=$ Discounted Benefit in proportion to Discounted Cost.

i) if $\mathrm{BCR}>$ accept the project proposed

ii) if $\mathrm{BCR}<$ reject the project

iii) if $\mathrm{BCR}=$ the project will have no effect whether accepted or rejected

Internal Rate of Return (IRR): The IRR indicates the extent to which proportionally benefits exceed costs. Here the excess is expressed as a return on the project's cost. It gives a particular set of annual net benefit, an NPV of zero (0). The IRR is useful when considering the way in which projects are financed; it can be compared to the rate of interest that would have to be paid by the project if all resources costs were financed through borrowing,

Mathematically, the IRR is defined as the rate of discount:

Where $\mathrm{B}(\mathrm{t}), \mathrm{C}(\mathrm{t}), \mathrm{r}$, and $\mathrm{t}$ are as defined earlier Therefore $\mathbf{I R R}=\mathbf{a}=\mathbf{b} . \mathbf{c} / \mathbf{d}$

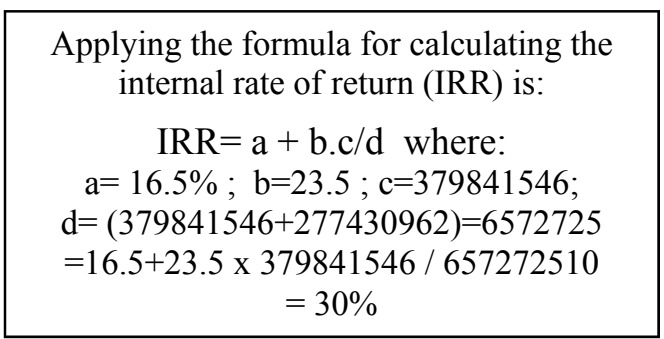


Where $a=$ the discount rate which gives positive NPV; $b=$ the discount rate which gives negative NPV; $\mathrm{c}=$ the positive NPV at the discount rate ' $\mathrm{a}$ '; and $\mathrm{d}=$ the total range of the NPV at the two discount rates chosen. For example the calculation of the IRR under the monthly payment regime of $₫ 30000$ is as follows:

At the decision making criterion using IRR as the criterion at a discount rate $\mathrm{R}$,

iv) if IRR $>$ accept the project proposed

v) if IRR $<$ reject the project

vi) if IRR = the project will have no effect whether accepted or rejected

The financial analysis was undertaken using the threshold amounts the residents in Takoradi were willing to pay for the private house to house solid waste collection system to be introduced. The thresholds which were derived through the fieldwork comprised $₫ 25,000, \notin 30,000$ and $₫ 35,000$. To identify the payment regime which would be profitable to private investors and yet acceptable to the clients (the residents), the payment regimes were subjected to sensitivity analysis, conducted with reference to inflationary trends. The prevailing or then current inflationary rate (INFc), the case of inflation rate falling below (INFb) and inflation rate rising (INFa) were considered at the instance of each of the three (3) willingness to pay valuespecific regimes. The quantitative outcomes of the financial analysis are as set out in tables $4 \mathrm{a}, 4 \mathrm{~b}, 5 \mathrm{a}, 5 \mathrm{~b}$, $6 \mathrm{a}$, and $6 \mathrm{~b}$. The sensitivity analysis of three price regimes $(ф 25,000, ф 30,000$ and $₫ 35,000)$ were used to generate alternative scenarios

Table 4a. At a willingness to pay rate of 25000 cedis per house per month at the prevailing inflationary rate of

\begin{tabular}{|c|c|c|c|c|c|c|c|c|c|}
\hline Year & $\begin{array}{l}\text { Capital } \\
\text { Costs }\end{array}$ & $\begin{array}{c}\text { Costs } \\
\text { Depreciation }\end{array}$ & $\begin{array}{c}\text { Running } \\
\text { Costs }\end{array}$ & Total Costs & $\begin{array}{c}\text { Total } \\
\text { Benefit }\end{array}$ & Net Benefit & $\begin{array}{c}\text { Discount } \\
\text { Factor }\end{array}$ & $\begin{array}{c}\text { Discounted } \\
\text { Cost }\end{array}$ & $\begin{array}{l}\text { Discounted } \\
\text { Benefits }\end{array}$ \\
\hline 0 & 800000000 & 68571429 & 0 & 800000000 & 0 & -800000000 & 1 & 800000000 & 0 \\
\hline 1 & 0 & 68571429 & $371,076,420$ & $371,076,420$ & 561000000 & $189,923,580$ & 1.17 & 317159333.3 & 479487179.5 \\
\hline 2 & 0 & 68571429 & $371,076,420$ & $371,076,420$ & 561000000 & $189,923,580$ & 1.37 & 270858700.7 & 409489051.1 \\
\hline 3 & 0 & 68571429 & $371,076,420$ & $371,076,420$ & 561000000 & $189,923,580$ & 1.6 & 231922762.5 & 350625000 \\
\hline 4 & 0 & 68571429 & $371,076,420$ & $371,076,420$ & 561000000 & $189,923,580$ & 1.87 & 198436588.2 & 300000000 \\
\hline 5 & 0 & 68571429 & $371,076,420$ & $371,076,420$ & 561000000 & $189,923,580$ & 2.19 & 169441287.7 & 256164383.6 \\
\hline 6 & 0 & 68571429 & $371,076,420$ & $371,076,420$ & 561000000 & $189,923,580$ & 2.57 & 144387712.1 & 218287937.7 \\
\hline 7 & 0 & 68571429 & $371,076,420$ & $371,076,420$ & 561000000 & $189,923,580$ & 3 & 123692140 & 187000000 \\
\hline 8 & 800000000 & 0 & $371,076,420$ & $1,171,076,420$ & 881000000 & $-290,076,420$ & 3.51 & 333640005.7 & 250997151 \\
\hline 9 & 0 & 68571429 & $371,076,420$ & $371,076,420$ & 561000000 & $189,923,580$ & 4.11 & 90286233.58 & 136496350.4 \\
\hline \multirow[t]{3}{*}{10} & 0 & 68571429 & $371,076,420$ & $371,076,420$ & 561000000 & $189,923,580$ & 4.81 & 77146864.86 & 116632016.6 \\
\hline & & & & & & $619,235,800$ & & 2756971629 & 2705179070 \\
\hline & & & & & & at $16.5 \%$ & & $\mathrm{NPV}=$ & -51792558.79 \\
\hline
\end{tabular}

Table $4 \mathrm{~b}$ At a willingness to pay rate of 25000 cedis per house per month and the reduced inflationary rate of $11.5 \%$

\begin{tabular}{|c|c|c|c|c|c|c|c|c|c|}
\hline Year & $\begin{array}{c}\text { Capital } \\
\text { Costs }\end{array}$ & $\begin{array}{c}\text { Costs } \\
\text { Depreciation }\end{array}$ & $\begin{array}{c}\text { Running } \\
\text { Costs }\end{array}$ & Total Costs & Total Benefit & Net Benefit & $\begin{array}{l}\text { Discount } \\
\text { Factor }\end{array}$ & $\begin{array}{c}\text { Discounted } \\
\text { Cost }\end{array}$ & $\begin{array}{c}\text { Discounted } \\
\text { Benefits }\end{array}$ \\
\hline 0 & 800000000 & 68571429 & 0 & 800000000 & 0 & -800000000 & 1 & 800000000 & 0 \\
\hline 1 & 0 & 68571429 & $371,076,420$ & $371,076,420$ & 561000000 & $189,923,580$ & 1.115 & 332803964.1 & 503139013.5 \\
\hline 2 & 0 & 68571429 & $371,076,420$ & $371,076,420$ & 561000000 & $189,923,580$ & 1.24 & 299255177.4 & 452419354.8 \\
\hline 3 & 0 & 68571429 & $371,076,420$ & $371,076,420$ & 561000000 & $189,923,580$ & 1.39 & 266961453.2 & 403597122.3 \\
\hline 4 & 0 & 68571429 & $371,076,420$ & $371,076,420$ & 561000000 & $189,923,580$ & 1.55 & 239404141.9 & 361935483.9 \\
\hline 5 & 0 & 68571429 & $371,076,420$ & $371,076,420$ & 561000000 & $189,923,580$ & 1.72 & 215742104.7 & 326162790.7 \\
\hline 6 & 0 & 68571429 & $371,076,420$ & $371,076,420$ & 561000000 & $189,923,580$ & 1.92 & 193268968.8 & 292187500 \\
\hline 8 & 800000000 & 0 & $371,076,420$ & $1,171,076,420$ & 881000000 & $-290,076,420$ & 2.39 & 489990133.9 & 368619246.9 \\
\hline 9 & 0 & 68571429 & $371,076,420$ & $371,076,420$ & 561000000 & $189,923,580$ & 2.66 & 139502413.5 & 210902255.6 \\
\hline \multirow[t]{3}{*}{10} & 0 & 68571429 & $371,076,420$ & $371,076,420$ & 561000000 & $189,923,580$ & 2.97 & 124941555.6 & 188888888.9 \\
\hline & & & & & & $619,235,800$ & & 3275270109 & 3370001189 \\
\hline & & & & & & at $11.5 \%$ & & $\mathrm{NPV}=$ & 94731079.9 \\
\hline
\end{tabular}

For the IRR, IRR=a + b.c/d a= 11.5\% $\quad b=5 \quad c=94731079.9 \quad d=94731079.9+51792558.79 \quad d=146523638$

$=11.5+5 * 94731079.9 / 146523638=14.7 \%$

Table 5a At a willingness to pay rate of 30000 cedis per house per month at the prevailing inflationary rate of $16.5 \%$. 


\begin{tabular}{|c|c|c|c|c|c|c|c|c|c|}
\hline Year & $\begin{array}{c}\text { Capital } \\
\text { Costs }\end{array}$ & $\begin{array}{c}\text { Costs } \\
\text { Depreciation }\end{array}$ & $\begin{array}{l}\text { Running } \\
\text { Costs }\end{array}$ & Total Costs & $\begin{array}{c}\text { Total } \\
\text { Benefit }\end{array}$ & Net Benefit & $\begin{array}{l}\text { Discount } \\
\text { Factor }\end{array}$ & $\begin{array}{c}\text { Discounted } \\
\text { Cost }\end{array}$ & $\begin{array}{c}\text { Discounted } \\
\text { Benefits }\end{array}$ \\
\hline $\mathbf{0}$ & 800000000 & 68571429 & 0 & 800000000 & 0 & -800000000 & 1 & 800000000 & 0 \\
\hline 1 & 0 & 68571429 & $371,076,420$ & $371,076,420$ & 673200000 & $302,123,580$ & 1.17 & 317159333.3 & 575384615 \\
\hline 2 & 0 & 68571429 & $371,076,420$ & $371,076,420$ & 673200000 & $302,123,580$ & 1.37 & 270858700.7 & 491386861 \\
\hline 3 & 0 & 68571429 & $371,076,420$ & $371,076,420$ & 673200000 & $302,123,580$ & 1.6 & 231922762.5 & 420750000 \\
\hline 4 & 0 & 68571429 & $371,076,420$ & $371,076,420$ & 673200000 & $302,123,580$ & 1.87 & 198436588.2 & 360000000 \\
\hline 5 & 0 & 68571429 & $371,076,420$ & $371,076,420$ & 673200000 & $302,123,580$ & 2.19 & 169441287.7 & 307397260 \\
\hline 6 & 0 & 68571429 & $371,076,420$ & $371,076,420$ & 673200000 & $302,123,580$ & 2.57 & 144387712.1 & 261945525 \\
\hline 7 & 0 & 68571429 & $371,076,420$ & $371,076,420$ & 673200000 & $302,123,580$ & 3 & 123692140 & 224400000 \\
\hline 8 & 800000000 & 0 & $371,076,420$ & $1,171,076,420$ & 673200000 & $-497,876,420$ & 3.51 & 333640005.7 & 191794872 \\
\hline 9 & 0 & 68571429 & $371,076,420$ & $371,076,420$ & 673200000 & $302,123,580$ & 4.11 & 90286233.58 & 163795620 \\
\hline \multirow[t]{3}{*}{10} & 0 & 68571429 & $371,076,420$ & $371,076,420$ & 673200000 & $302,123,580$ & 4.81 & 77146864.86 & 139958420 \\
\hline & & & & & & $1,421,235,800$ & & 2756971629 & 3136813174 \\
\hline & & & & & & & at $16.5 \%$ & $\mathrm{NPV}=$ & 379841546 \\
\hline
\end{tabular}

Table 5b For the IRR, At a willingness to pay rate of 30000 cedis per house per month at an increased inflationary rate

\begin{tabular}{|c|c|c|c|c|c|c|c|c|c|}
\hline Year & Capital Costs & $\begin{array}{l}\text { Costs } \\
\text { Depreciation }\end{array}$ & $\begin{array}{l}\text { Running } \\
\text { Costs }\end{array}$ & Total Costs & $\begin{array}{l}\text { Total } \\
\text { Benefit }\end{array}$ & Net Benefit & $\begin{array}{l}\text { Discount } \\
\text { Factor }\end{array}$ & $\begin{array}{l}\text { Discounted } \\
\text { Cost }\end{array}$ & $\begin{array}{c}\text { Discounted } \\
\text { Benefits }\end{array}$ \\
\hline 0 & 800000000 & 68571429 & 0 & 800000000 & 0 & -800000000 & 1 & 800000000 & 0 \\
\hline 1 & 0 & 68571429 & $371,076,420$ & $371,076,420$ & 673200000 & $302,123,580$ & 1.4 & 265054585.7 & 480857143 \\
\hline 2 & 0 & 68571429 & $371,076,420$ & $371,076,420$ & 673200000 & $302,123,580$ & 196 & 1893247.041 & 3434693.88 \\
\hline 3 & 0 & 68571429 & $371,076,420$ & $371,076,420$ & 673200000 & $302,123,580$ & 2.74 & 135429350.4 & 245693431 \\
\hline 4 & 0 & 68571429 & $371,076,420$ & $371,076,420$ & 673200000 & $302,123,580$ & 3.84 & 96634484.38 & 175312500 \\
\hline 5 & 0 & 68571429 & $371,076,420$ & $371,076,420$ & 673200000 & $302,123,580$ & 5.38 & 68973312.27 & 125130112 \\
\hline 6 & 0 & 68571429 & $371,076,420$ & $371,076,420$ & 673200000 & $302,123,580$ & 7.53 & 49279737.05 & 89402390.4 \\
\hline 7 & 0 & 68571429 & $371,076,420$ & $371,076,420$ & 673200000 & $302,123,580$ & 10.54 & 35206491.46 & 63870967.7 \\
\hline 8 & 800000000 & 0 & $371,076,420$ & $1,171,076,420$ & 673200000 & $-497,876,420$ & 14.76 & 79341220.87 & 45609756.1 \\
\hline 9 & 0 & 68571429 & $371,076,420$ & $371,076,420$ & 673200000 & $302,123,580$ & 20.66 & 17961104.55 & 32584704.7 \\
\hline \multirow[t]{3}{*}{10} & 0 & 68571429 & $371,076,420$ & $371,076,420$ & 673200000 & $302,123,580$ & 28.92 & 12831134.85 & 23278008.3 \\
\hline & & & & & & $1,421,235,800$ & & 1562604669 & \\
\hline & & & & & & & at $40.0 \%$ & $\mathrm{NPV}=$ & $\begin{array}{l}1285173706 \\
-277430962\end{array}$ \\
\hline
\end{tabular}

For the IRR, IRR= a + b.c/d $\quad a=16.5 \% \quad b=23.5 \quad c=379841546 \mathrm{~d}=379841546+277430962 \quad \mathrm{~d}=6572725 \quad=16.5+23.5 * 379841546 /$ $657272510=$

Table 6a. At a willingness to pay rate of 35000 cedis per house per month and using the prevailing inflationary rate of $16.5 \%$

\begin{tabular}{|c|c|c|c|c|c|c|c|c|c|}
\hline Year & $\begin{array}{l}\text { Capital } \\
\text { Costs }\end{array}$ & $\begin{array}{l}\text { Costs } \\
\text { Depreciation }\end{array}$ & $\begin{array}{l}\text { Running } \\
\text { Costs }\end{array}$ & Total Costs & Total Benefit & Net Benefit & $\begin{array}{l}\text { Discount } \\
\text { Factor }\end{array}$ & $\begin{array}{l}\text { Discounted } \\
\text { Cost }\end{array}$ & $\begin{array}{r}\text { Discounted } \\
\text { Benefits }\end{array}$ \\
\hline $\mathbf{0}$ & 800000000 & 68571429 & 0 & 800000000 & 0 & -800000000 & 1 & 800000000 & 0 \\
\hline 1 & 0 & 68571429 & $371,076,420$ & $371,076,420$ & 785400000 & $414,323,580$ & 1.17 & 317159333.3 & 671282051 \\
\hline 2 & 0 & 68571429 & $371,076,420$ & $371,076,420$ & 785400000 & $414,323,580$ & 1.37 & 270858700.7 & 573284672 \\
\hline 3 & 0 & 68571429 & $371,076,420$ & $371,076,420$ & 785400000 & $414,323,580$ & 1.6 & 231922762.5 & 490875000 \\
\hline 4 & 0 & 68571429 & $371,076,420$ & $371,076,420$ & 785400000 & $414,323,580$ & 1.87 & 198436588.2 & 420000000 \\
\hline 5 & 0 & 68571429 & $371,076,420$ & $371,076,420$ & 785400000 & $414,323,580$ & 2.19 & 169441287.7 & 358630137 \\
\hline 6 & 0 & 68571429 & $371,076,420$ & $371,076,420$ & 785400000 & $414,323,580$ & 2.57 & 144387712.1 & 305603113 \\
\hline 7 & 0 & 68571429 & $371,076,420$ & $371,076,420$ & 785400000 & $414,323,580$ & 3 & 123692140 & 261800000 \\
\hline 8 & 800000000 & 0 & $371,076,420$ & $1,171,076,420$ & 1105400000 & $-65,676,420$ & 3.51 & 333640005.7 & 314928775 \\
\hline 9 & 0 & 68571429 & $371,076,420$ & $371,076,420$ & 785400000 & $414,323,580$ & 4.11 & 90286233.58 & 191094891 \\
\hline \multirow[t]{3}{*}{10} & 0 & 68571429 & $371,076,420$ & $371,076,420$ & 785400000 & $414,323,580$ & 4.81 & 77146864.86 & 163284823 \\
\hline & & & & & & $2,863,235,800$ & & 2756971629 & 3750783461 \\
\hline & & & & & & & at $16.5 \%$ & $\mathrm{NPV}=$ & 993811833 \\
\hline
\end{tabular}

Table 6b. At a willingness to pay rate i of 35000 cedis per house per month and using an increased inflationary rate of $40 \%$, for a negative $\mathrm{NPV}$,

\begin{tabular}{|c|c|c|c|c|c|c|c|c|c|}
\hline Year & Capital Costs & $\begin{array}{l}\text { Costs } \\
\text { Depreciation }\end{array}$ & $\begin{array}{l}\text { Running } \\
\text { Costs }\end{array}$ & Total Costs & $\begin{array}{l}\text { Total } \\
\text { Benefit }\end{array}$ & Net Benefit & $\begin{array}{l}\text { Discount } \\
\text { Factor }\end{array}$ & $\begin{array}{l}\text { Discounted } \\
\text { Cost }\end{array}$ & $\begin{array}{r}\text { Discounted } \\
\text { Benefits }\end{array}$ \\
\hline 0 & 800000000 & 68571429 & 0 & 800000000 & 0 & -800000000 & 1 & 800000000 & 0 \\
\hline 1 & 0 & 68571429 & $371,076,420$ & $371,076,420$ & 785400000 & $414,323,580$ & 1.4 & 265054585.7 & 561000000 \\
\hline 2 & 0 & 68571429 & $371,076,420$ & $371,076,420$ & 785400000 & $414,323,580$ & 196 & 1893247.041 & 4007142.86 \\
\hline 3 & 0 & 68571429 & $371,076,420$ & $371,076,420$ & 785400000 & $414,323,580$ & 2.74 & 135429350.4 & 286642336 \\
\hline 4 & 0 & 68571429 & $371,076,420$ & $371,076,420$ & 785400000 & $414,323,580$ & 3.84 & 96634484.38 & 204531250 \\
\hline 5 & 0 & 68571429 & $371,076,420$ & $371,076,420$ & 785400000 & $414,323,580$ & 5.38 & 68973312.27 & 145985130 \\
\hline
\end{tabular}




\begin{tabular}{|c|c|c|c|c|c|c|c|c|c|}
\hline 6 & 0 & 68571429 & $371,076,420$ & $371,076,420$ & 785400000 & $414,323,580$ & 7.53 & 49279737.05 & 104302789 \\
\hline 7 & 0 & 68571429 & $371,076,420$ & $371,076,420$ & 785400000 & $414,323,580$ & 10.54 & 35206491.46 & 74516129 \\
\hline 8 & 800000000 & 0 & $371,076,420$ & $1,171,076,420$ & 1105400000 & $-65,676,420$ & 14.76 & 79341220.87 & 74891598.9 \\
\hline 9 & 0 & 68571429 & $371,076,420$ & $371,076,420$ & 785400000 & $414,323,580$ & 20.66 & 17961104.55 & 38015488.9 \\
\hline \multirow[t]{2}{*}{10} & 0 & 68571429 & $371,076,420$ & $371,076,420$ & 785400000 & $414,323,580$ & 28.92 & 12831134.85 & 27157676.3 \\
\hline & & & & & & $2,863,235,800$ & at $40 \%$ & $\begin{array}{l}1562604669 \\
\text { NPV }=\end{array}$ & $\begin{array}{l}1521049541 \\
-\mathbf{4 1 5 5 5 1 2 7 . 8}\end{array}$ \\
\hline
\end{tabular}

Viability of Private Sector Participation

Considering the willingness to pay the $\phi 25,000$ value specific regime per house monthly rate at the prevailing inflation rate (INFC) of 16.5 percent, the attendant net present value of the anticipated investment is negative -51792558.79 (table 4a). A negative net present value as such implies that the project is not viable for private investors to undertake. The benefit-cost ratio which expresses the total benefit as a proportion of the total cost is less than one (0.98), which is not as such attractive to investors because they cannot make any profit. A benefits-costs ratio of 1:1 would have meant that total cost equals total revenue, a more or less break-even situation. Any possible rise (INFa) in inflation from the current (INFc) level is detrimental to the project proposition since more costs will be incurred with no apparent gains.

However, if the prevailing inflation rate (INFc) of 16.5 percent were to drop to 11.5 percent (INFb) the project would have been viable, since it would have had a positive net present value of 94731079.9 (table $4 \mathrm{~b})$. The internal rate of return which indicates profit as a percentage of costs is, however, not very impressive ( 14.7 percent) if the residents pay $\notin 25,000$ per house monthly.

A drop in inflation is a macroeconomic issue beyond the scope of the capability of the private investor. This has implications for private investors who are profit-motivated. Private investors would not want to invest under conditions of the low internal rate of return and negative net present value, and would therefore negotiate for a higher fee. The $\phi 25,000$ per house monthly payment regime would hold if the government decides to subsidise the rate considering the prevailing economic exigencies of the people's ability to pay and the social significance of sanitation to the populace.

Refuse collection in Takoradi at the monthly payment of $₫ 30,000$ per house at the prevailing inflation rate $(\mathrm{INF})$ ) of 16.5 percent is viable. The net present value is positive standing at 379841546 and internal rate of return is 30 percent. The discounted benefit is 1.14 times the discounted cost. Even if inflation were to rise (INFa) as high as 35 percent the project would still have been viable. It would take an increased inflation rate (INFa) of as high as 40 percent for the project not to be viable. The benefits-costs ratio is higher than unity since profits far outweigh costs. Also, the internal rate of return is 30 percent (table $3 \mathrm{~b}$ ). The corollary for private firms under such circumstances will be the registration of high returns to their investments. Any reduction in the current inflationary rate $(\mathrm{INF} C)$ will make the project more feasible at the $£ 30,000$ per house monthly payment regime.

The scenario is much even brighter where the monthly rate of payment is $\notin 35,000$ per house at the inflation rate of 16.5 percent (table 6a). The project will be more feasible because the net present value (993811833) obtained is positive. The benefits-costs ratio (1.3) too is higher than 1. This means that profit (3750783461) far out weigh cost (2756971629). Also, the internal rate of return is 39.05 percent, far more than a quarter of the capital invested. In a similar manner, the inflation would have to rise (INFa) as high as 40 percent to make the project not viable (table $6 \mathrm{~b}$ ).

\section{CONCLUSION}

From the financial sensitivity analysis, it can be deduced that it is not feasible for private investors to undertake the house to house solid waste collection project under the willingness to pay the $\phi 25,000$ value specific regime. They cannot make any profit at the prevailing inflation rate (INFc) of 16.5 percent. Gains can, however, be made at a reduced inflation rate (INFb) beyond 11.5 percent. Nevertheless, it is this payment regime ( $\$ 25,000$ per month) that the majority (63 percent) of the residents in Takoradi are willing to pay.

Under the willingness to the payment of $₫ 30,000$ regime, private investors can venture into business not only at the prevailing inflation rate (INFc) or under conditions of reducing inflation rate (INFb) but also even under a rising inflation rate (INFa) of up to 35 percent. However, 27 percent of the residents in Takoradi are willing to pay that rate. 
The $\phi 35,000$ payment regime is quite acceptable because investors can do business because they can make profit at the prevailing rate (INFc) of 16.5 percent. If inflation drops from the current rate they can even make more profit. An increasing inflation rate (INFa) is not so detrimental since it would take up to $40 \%$ to get the business not to be profitable. Only 10 percent of the project clients in Takoradi are willing to pay the $\phi 35,000$ per month for the services of a private contractor.

In conclusion the $\phi 30,000$ regime is recommended but since only about one-third the people are willing to pay, it will require public education for the residents to understand and take up the challenge in return for better service delivery from the private sector. At the same time, private participation can be encouraged through sensitization of the private contractors to acknowledge and enlighten them of the business potential in the privatization of solid waste management. Every entrepreneur left on his own will like to make as much profit as practicable but this could be abnormal from the social perspective. A regulatory mechanism needs to be in place to control. In Takoradi, the relevant authority is the Shama Ahanta East Metropolitan Area.

\section{REFERENCES}

Bartone C. R. (1991). Private Sector Participation in Municipal Solid Waste Services: Experiences in Latin America, Washington D.C. World Bank.

Budds, J. and Gordon, Mc G. (2003). Are the Debates on Water Privatisation Missing the Point? Experiences from Africa, Asia and Latin America, Environment Urbanization, Vol. 15, No.2, pages 87113.

Burra, S., Petel, S. and Kerr, T. (2003). Community-Designed Built and Managed Toilet Blocks in Indian Cities., Environment and Urbanization vol.15, No.2 October pages11-32.

Chaplin; S. E. (1999). Social Exclusion and the Politics of Sanitation in Urban India, "Environment and Urbanization Vol.11, No.1 April pages 145-158.

Cointreau-Levine, S. (1994). Private Sector Participation in Municipal Solid Waste Services in Developing Countries, The Formal Sector, Vol. 1, Washington D.C; World Bank.

Donahue, J.D. (1989). Privatisation Decision Public Ends Private Means, Basic Books Publishers, New York.

Fransen F.H. (1999). A Report on the Training Programme Within the Framework of the Urban Environmental Sanitation Project (UESP) in Ghana, Washington D.C., World Bank.

Ghana Statistical Service, (2002). 2000 Population and Housing Census, Special Report on urban Localities.

Gutierrez, E. (2001). Framework Document: A Survey of Theoretical Issues on Private Sector Participation in Water and Sanitation, cited in: Budds, Jessica and Gordon, Environment Urbanization. Vol.15, No.2: pages 87-.91.

Hartman R. (1995). Solid Waste Management: Options for Private Sector Participation, GTZ, office Tunisia.

Idelovitch, E. and Ringskog, (1995). Private Sector Participation in Water Supply and Sanitation in Latin America, Washington D.C World Bank.

Kasanga, R.K. and Avis M.R. (1988). Internal Migration and urbanisation in Developing Countries, Finding from Ghana., Research Papers in Land Management and Development, Environment Policy, No. 1.

Land Valuation Board, (2004), Classification of Houses in Takoradi, Takoradi office

Moor, J. (2001). Hazard x Value = Risk, in:UN-Habitat United Nations Human Settlements Programme, UNHSP (UN-Habitat) Office Dec. Vol. No.4.

Skitts, J. (1979). Mediterranean Environmental Technical Assistance Programme Report, Washington D.C., World Bank.

Stottman, W. (2000). The Role of the Private Sector in Provision of Water and Waste Water Services in Urban Areas in: Uitto, Juha and Asit Biswas Water for Urban Areas, The United Nations Press. Tokyo.

Tibaijuka, Anna K. (2001). Cities, in: UN-Habitat United Nations Human Settlements Programme, UNHSP (UN-Habitat) Office Dec. Vol. No.4. 